\title{
Effect of pH and Dissolved Silicate on the Formation of Surface Passivation Layers for Reducing Pyrite Oxidation
}

\author{
Shengjia Zeng ${ }^{1}$, Jun Li $^{1}$, Russell Schumann ${ }^{2}$, Roger Smart ${ }^{1}$ \\ ${ }^{1}$ Minerals and Materials Science \& Technology, Mawson Institute \\ ${ }^{2}$ Levay\& Co.; University of South Australia, Adelaide, South Australia, Australia \\ Email: Shengjia.Zeng@unisa.edu.au
}

Received 2013

\begin{abstract}
Acid mine drainage (AMD)and toxic metal release generated by oxidation of sulphide minerals, particularly pyrite, in mine wastes, are a critical environmental issue worldwide. Currently, there are many options to diminish sulphide oxida- tion including barrier methods that isolate pyrite from oxygen or water, chemical additives and inhibition of iron-oxidizing bacteria. This study focuses on understanding the role that silicate and $\mathrm{pH}$ conditions play in the formation and stabilisation of pyrite surface passivation layers found in lab and field studies. The results from pyrite dissolution tests under various conditions showed that the pyrite oxidation rate has been reduced by up to $60 \%$ under neutral $\mathrm{pH}$ with additional soluble silicate. Solution speciation calculation predicted that crystalline goethite is formed in the experiment without silicate additionbutan amorphous iron hydroxide surface layer is stabilized by the addition of the silicate, inhibiting goethite formation and continuing pyrite oxidation. This coherent, continuous amorphous layer has been verified in SEM.
\end{abstract}

Keywords: Acid Mine Drainage; Pyrite; Passivation Coating; Silicate

\section{Introduction}

Acid mine drainage (AMD) is a critical global environmental issue from many mine wastes. The discharge of AMD with associated toxic metal release has caused acidification of water environment, leading to extermination of aquatic life and compromised water quality for agriculture and drinking. Sulphide oxidation of sulfidic minerals dominantly contributes to most of AMD issues at mining sites, and pyrite, the most abundant sulphide mineral in the earth's crust [1], is widely found in mining activities. Itsoxidation process under various conditions has been therefore widely studied to explore effective approaches and controlling factors to retard the oxidation process [2-5]. It is known that the oxidant (ferric ion or dissolved oxygen), water content and catalyst (i.e. iron oxidizing bacteria) have significant impact on the pyrite oxidation rate [6]. Reduction of any of these factors can contribute a remarkable reduction of the oxidation rate. The oxidant can be inhibited at pyrite particle surfaces by a surface barrier through the formation of passivation layers [2,3,7-10] and some coating agents, e.g. acetyl acetone, humic acids, ammonium lignosulfonates, oxalic acid and sodium silicate, were reported to be employedfor pyrite surface treatmentbut only minor reductions in pyrite oxidation rates resulted $[1,3,9,11]$. Huminicki and Rimstidt [12] reported that precipitation of iron hydrox- ide particle reduced oxidant's diffusion coefficient by more than five orders of magnitude. Evangelou [8] introduced a more stableiron hydroxide/silica coating generated via precipitation of an Fe-Si complex. Smart et al. [13] and Miller et al. [14] found from their long term column leaching and field studies at the Grasberg mine Indonesia that silicate may be responsible for stabilising the iron oxy-hydroxide passivation layer on pyrite surfaces. It was also reported from some of fund amental studies that silicate in hibits the trans formation ofamorphous iron hydroxide $\mathrm{Fe}(\mathrm{OH})_{3}$ to crystalline goethite $(\mathrm{FeOOH})$ in synthesis processes $[4,15,16]$. However, little has been known on the reaction path ways of the surface coating associated with silicate or the trans formation process of iron hydroxideprecipitated and coating stability. In this study, pyrite dissolution tests under various $\mathrm{pH}$ conditions in the presence of low concentrations of $\mathrm{Na}_{2} \mathrm{SiO}_{3}(10$ and $20 \mathrm{mg} / \mathrm{Lsilicate}$ as $\mathrm{Si}$ ), were performedto investigate the influence of $\mathrm{pH}$ and dissolved silicate on the stability of iron oxyhydroxide surface layers formed during oxidative dissolution of pyrite at circum-neutral $\mathrm{pH}$.

\section{Method and Materials}

Pyrite(particle size 38 - $75 \mu \mathrm{m}$ )obtained from Geo Discoveries (NSW, Australia) was leached under conditions 
shown in Table 1 Dissolved silicate, shown as Si concentrations from assays, has been chosen based on concentrations in effluent of column leach tests. Experiments were conducted at four different solution pHs (3.5, 4.5, 5.5 and $~ 8$ ) and with three concentrations of dissolved $\mathrm{Si}$ (none added, $10 \mathrm{mg} / \mathrm{L}$ and $20 \mathrm{mg} / \mathrm{L}$ added as sodium silicate).Solution samples were periodically taken for Fe, $\mathrm{S}$ and Si concentrations by ICP analysis as well as for solution Eh and $\mathrm{pH}$ measurements. Solution modelling software, PHREEQC [17], was used to predict the precipitation of possible secondary minerals based on measured Eh, pH and the dissolved element concentrations. This is a thermodynamic prediction of precipitates and solution species and requires experimental verification where possible. Scanning electron microscopy (SEM) was introduced to investigate the surface coating.

\section{Results and Discussion}

\subsection{Effect of pH and Silicate Concentrationonpyrite Oxidation}

Figure 1 shows pyrite oxidation rates plotted as a function of reaction time for each of the different solution $\mathrm{pH}$ and silicate concentrations examined. Oxidation rates were calculated from the total solution concentration (measured by ICP) in samples removed from the reactions throughout 160 days of dissolution. Initial oxidation rates
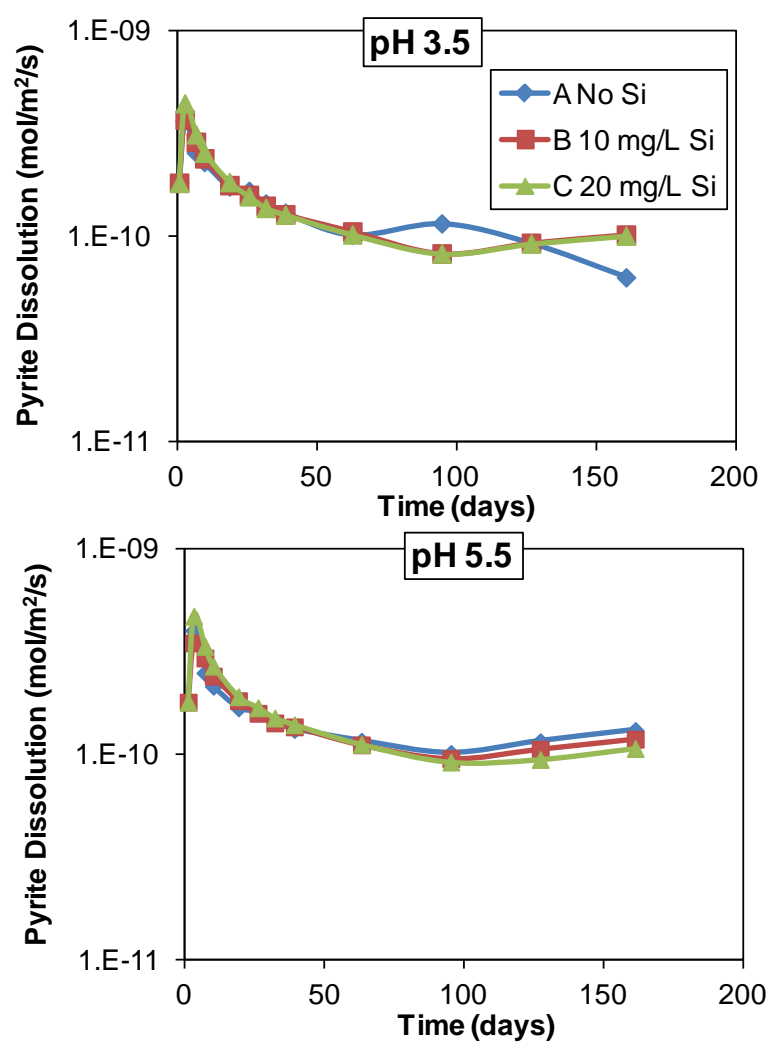

were between 3 and $4 \times 10^{-10} \mathrm{~mol} / \mathrm{m}^{2} / \mathrm{s}$ for all experiments, which decreased to around $1 \times 10^{-10} \mathrm{~mol} / \mathrm{m}^{2} / \mathrm{s}$ during about 100 days of oxidation for solution $\mathrm{pH}$ between 3.5 and 5.5 irrespective of how much silicate had been added. At the higher $\mathrm{pH}$ (near 8) of the saturated calcite solutions there was a difference in pyrite oxidation rates as a result of silicate addition. With no silicate added, pyrite oxidation rates in calcite saturated solution were about $60 \%$ fasterthan those at lower $\mathrm{pH}$ after about 40 days, while in the presence of $10-20 \mathrm{mg} / \mathrm{L} \mathrm{Si}$ the oxidation rates were slower at the higher $\mathrm{pH}$ of the calcite saturated solutions after about 40 days. The pyrite oxidation rate after about 100 days at circum-neutral $\mathrm{pH}$ and with $20 \mathrm{mg} / \mathrm{L} \mathrm{Si}$ added, was about half of the rate in similar solutions at lower $\mathrm{pH}$ (3.5 - 5.5).

Table 1. Experimental details of pyrite dissolution tests.

\begin{tabular}{|c|c|}
\hline Object & Description \\
\hline Pyrite & $\begin{array}{l}\text { 38-75 } \mu \mathrm{m} \text {, BET surface area: } 0.539 \mathrm{~m}^{2} / \mathrm{g} \text {, usage: } 2 \mathrm{~g} \\
\text { for each sample }\end{array}$ \\
\hline Calcite & 38-75 $\mu \mathrm{m}$, usage: $1.66 \mathrm{~g}$ (mole ratio: $1: 1$ with pyrite), \\
\hline Solution A & $1 \mathrm{~L}$ of $0.01 \mathrm{~mol} / \mathrm{l} \mathrm{KCl}$, No Si addition \\
\hline Solution B & $1 \mathrm{~L}$ of $0.01 \mathrm{~mol} / \mathrm{KCl}, 10 \mathrm{mg} / \mathrm{LSi}\left(\mathrm{Na}_{2} \mathrm{SiO}_{3}\right)$ \\
\hline Solution C & $1 \mathrm{~L}$ of $0.01 \mathrm{~mol} / \mathrm{l} \mathrm{KCl}, 20 \mathrm{mg} / \mathrm{LSi}\left(\mathrm{Na}_{2} \mathrm{SiO}_{3}\right)$ \\
\hline $\mathrm{pH}$ & $\begin{array}{l}\text { Manually controlled at } \mathbf{3 . 5}, \mathbf{4 . 5} \text { and } \mathbf{5 . 5} \\
\text { or buffered around } \mathbf{8 b y} \text { calcite }\end{array}$ \\
\hline
\end{tabular}
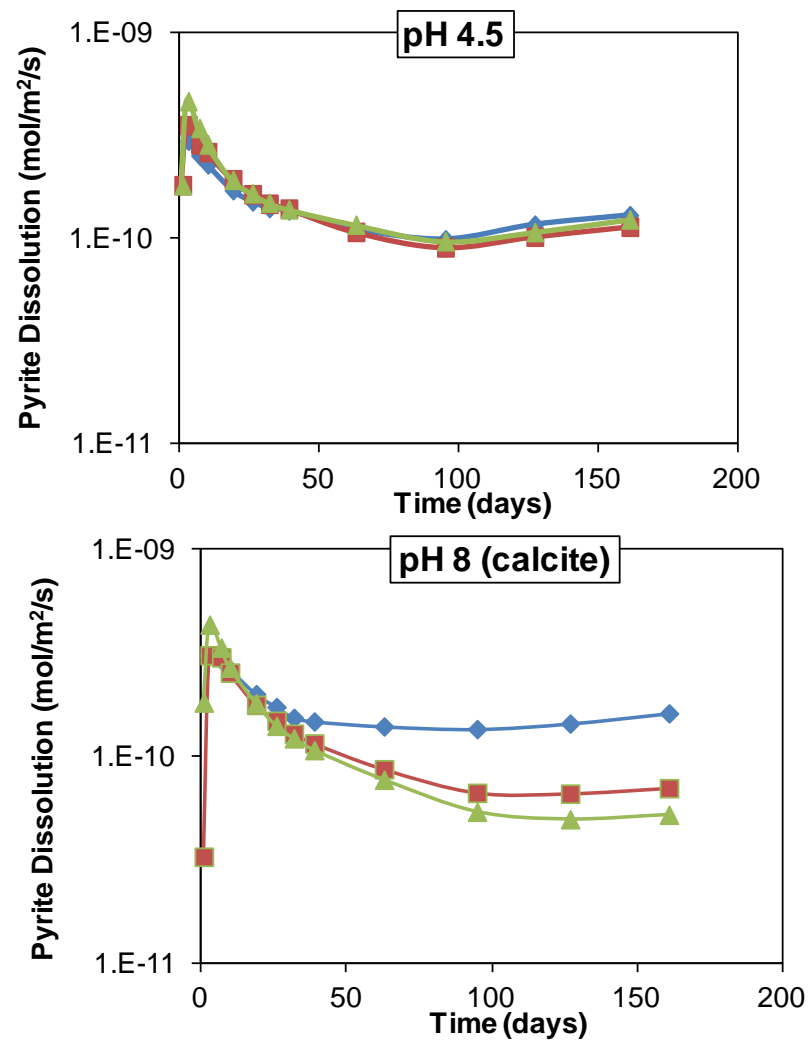

Figure 1. Pyrite dissolution rates as function of time at different solution $\mathrm{pH}$ and silicate concentrations. 
The decreasing oxidation rate as a function of time is indicative of passivating iron oxy-hydroxide layer formation found in SEM studies of lab and field samples [13, 14]. These results suggest that across the $\mathrm{pH}$ range 3.5 to 5.5 , neither the $\mathrm{pH}$ nor the concentration of silicate affect the nature of the iron oxy-hydroxide layer that forms as oxidation proceeds. However at the higher $\mathrm{pH}$ of calcite saturated solution there appears to be a clear influence of silicate on the oxidation rate, suggesting that increasing solution silicate concentration results in surface layers that are less permeable to oxygen and more stable.

\subsection{Change in Solution Fe concentrations}

Figure 2 shows solution iron concentrations as a function of time for all of the pyrite oxidation experiments. Not unexpectedly, there is a strong correlation between the solution $\mathrm{pH}$ and solution iron concentration, with higher concentrations in the lower $\mathrm{pH}$ solutions. During the first 10 days of pyrite oxidation at $\mathrm{pH} 3.5$ and 4.5 there was stoichiometric dissolution of iron and sulphur. After this time, the ratio of iron to sulphur decreased below two, indicative of iron oxy-hydroxide precipitation [12]. At pH 5.5 and in saturated calcite solution the ratio of iron to sulphur in solution was less than two from the
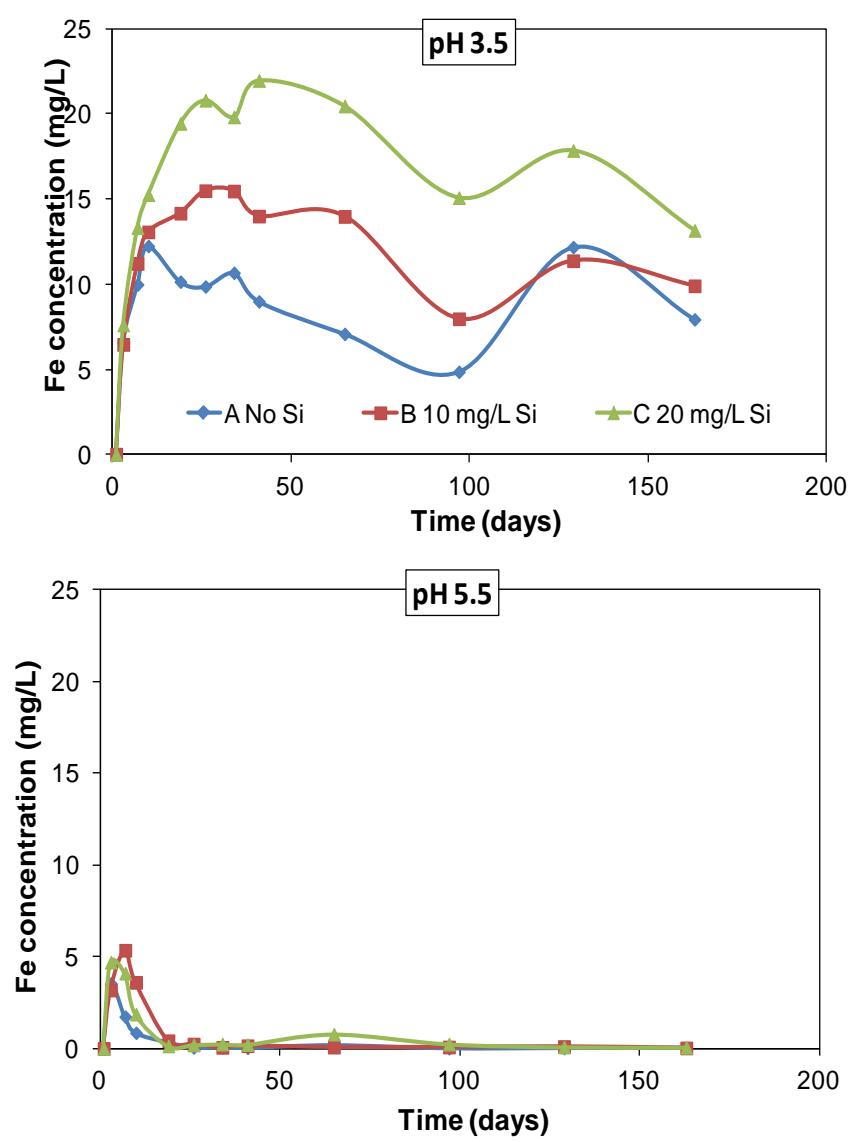

start, indicating formation of passivating layers from the beginning. Despite these differences, as discussed above, there appears to be no difference in pyrite oxidation rates with silicate addition except for oxidation in calcite saturated solution after about 40 days. While these results may suggest differences in the amount of precipitated iron oxy-hydroxide, this does not appear to strongly influence the oxidation rate in solutions with $\mathrm{pH}$ between 3.5 and 5.5 .

After about 100 days, there was a small increase in the concentration of iron in the solutions at $\mathrm{pH} 3.5$ and 4.5. This corresponds with a slight increase in the oxidation rate and may suggest some dissolution of the iron oxyhydroxide coating at lower $\mathrm{pH}$ values [12].

The data shown in Figure 2 also indicate a correlation between the concentration of iron in solution and that of silicate. They suggest that iron may be stabilized by complexation with silicate enhancing its solubility at the lower $\mathrm{pH}$ values. Other investigations on the influence of silicate on pyrite oxidation have shown that, at higher silicate concentrations than those used here and at lower $\mathrm{pH}$, pyrite oxidation is actually enhanced in the presence of silicate, possibly due to stabilization of Fe (III) by complexation with silicate [4].
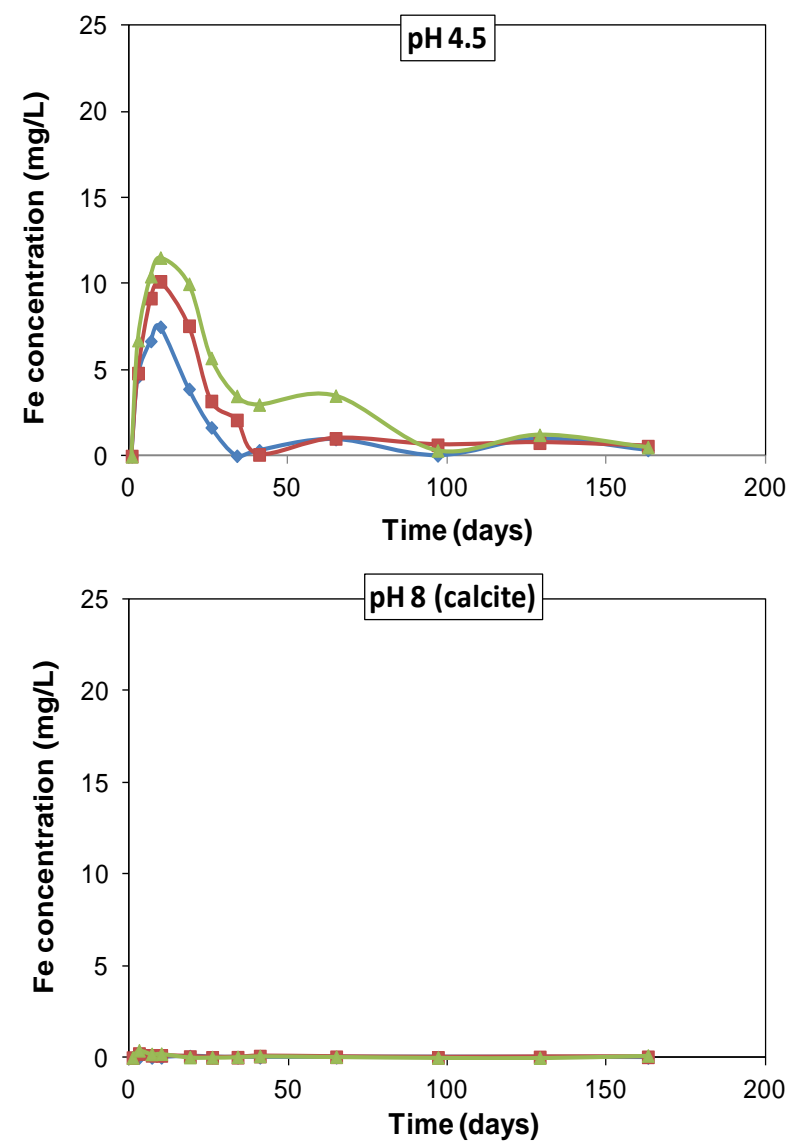

Figure 2. Iron concentration as function of time and $\mathrm{pH}$. 


\subsection{Change in Solution Si Concentrations}

Figure 3 shows solution $\mathrm{Si}$ concentrations as a function of time for all of the pyrite oxidation experiments except series A where no silicate was added and silicon concentrations were generally non-detectable $(<0.05 \mathrm{mg} / \mathrm{L})$. There appears to be a clear correlation between solution $\mathrm{pH}$ and the concentration of silicon in solution. At $\mathrm{pH} 3.5$ there is little decrease in the concentration of Si during the 160 days of the experiments. At the circum-neutral $\mathrm{pH}$ conditions of oxidation in calcite saturated solution there is close to a $50 \%$ decrease in the concentration of silicate, suggesting adsorption and/or precipitation of silicate with iron oxy-hydroxide. These results suggest that as the $\mathrm{pH}$ increases there is likely to be an increase in the amount of silicate in the iron oxy-hydroxide coating passivating the pyrite surface. However, as discussed above this does not appear to have influenced oxidation rates except in the case of oxidation at circum-neutral $\mathrm{pH}$. It therefore appears that a combination of both relatively high silicate concentration and neutral to high $\mathrm{pH}$ is required to have a significant effect on the oxygen permeability of iron oxy-hydroxide layers formed during pyrite oxidation.

\subsection{Speciation Calculations}

Speciation calculations for the pyrite dissolution experiments conducted in calcite saturated solutions predict that goethite is saturated both in the presence and absence of added silicate (Table 2). In contrast, amorphous iron hydroxide is predicted to be unsaturated in the absence of added silicate suggesting that conversion to goethite via dissolution and re-precipitation is thermodynamically likely. However, in the solution to which 20 $\mathrm{mg} / \mathrm{L}$ silicate (as $\mathrm{Si}$ ) has been added, speciation calculations predict that amorphous iron hydroxide is saturated indicating increased stability of the amorphous phase in the presence of silicate. These results are consistent with

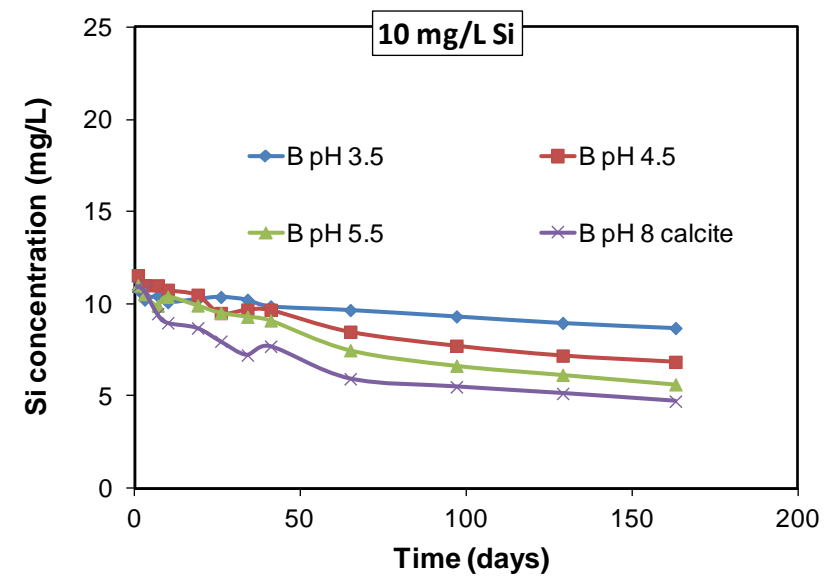

the observations of silicate -stabilized amorphous iron hydroxide and retarded the crystallization of goethite reported in literature $[4,15,18,19]$.

\subsection{Pyrite Surface Analysis}

Scanning electron microscopy (SEM) was applied to identify whether iron ox-hydroxide coatings formed on pyrite particles which have slowed pyrite oxidation as the reaction has proceeded, suggested by the oxidation rate data and solution analysis. Figure 4 shows SEM images of pyrite particles sampled from dissolution experiments conducted in calcite-saturated solution. The top images display the surface of pyrite after 160 days dissolution in a solution where no silicate has been added. An iron ox-hydroxide coating is clearly visible with a needle-like morphology suggestive of a crystalline goethite structure. The bottom images show pyrite particles taken after 160 days from a saturated calcite solution to which $20 \mathrm{mg} / \mathrm{L}$ silicate (as $\mathrm{Si}$ ) had been added. Again an iron ox-hydroxide coating is obvious on the pyrite surface, however, with very different morphology to that on pyrite from the solution in which no silicate had been added. In this instance the coating appears to be of a more amorphous nature. The Energy dispersed spectroscopy (EDS) spectra of the pyrite particles shown in Figure 5

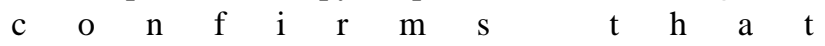

Table 2. Saturation indices (SI) of various mineral phases calculated using PHREEQC for saturated calcite solutions from pyrite dissolution with and without added silicate.

\begin{tabular}{ccc}
\hline Species & $\begin{array}{c}\text { SI } \\
\text { No added silicate }\end{array}$ & $\begin{array}{c}\text { SI } \\
20 \mathrm{mg} / \mathrm{L} \text { (as Si) } \\
\text { silicate added }\end{array}$ \\
\hline $\begin{array}{c}\text { Fe (OH) })_{3} \\
\text { (amorphous) }\end{array}$ & -0.2 & 0.5 \\
Goethite & 4.9 & 5.6 \\
\hline
\end{tabular}

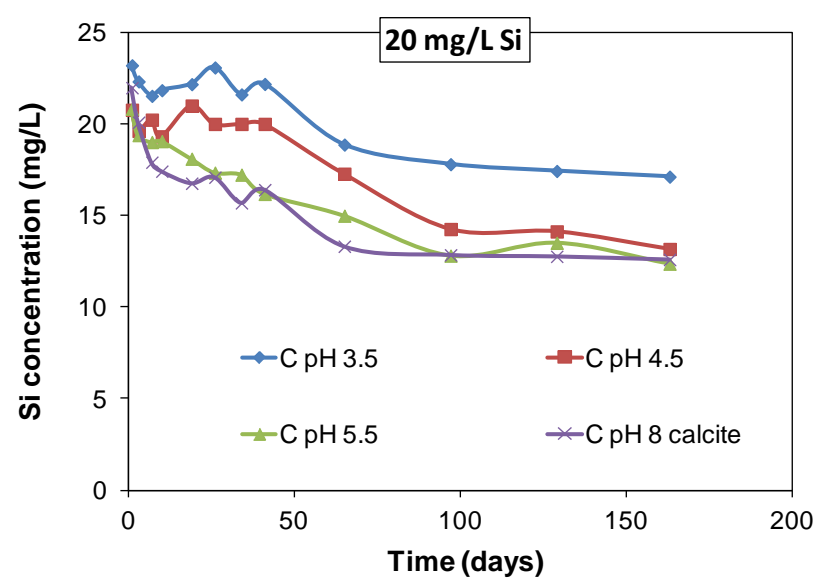


Figure 3. Silicate concentrations as function of time and $\mathrm{pH}$.

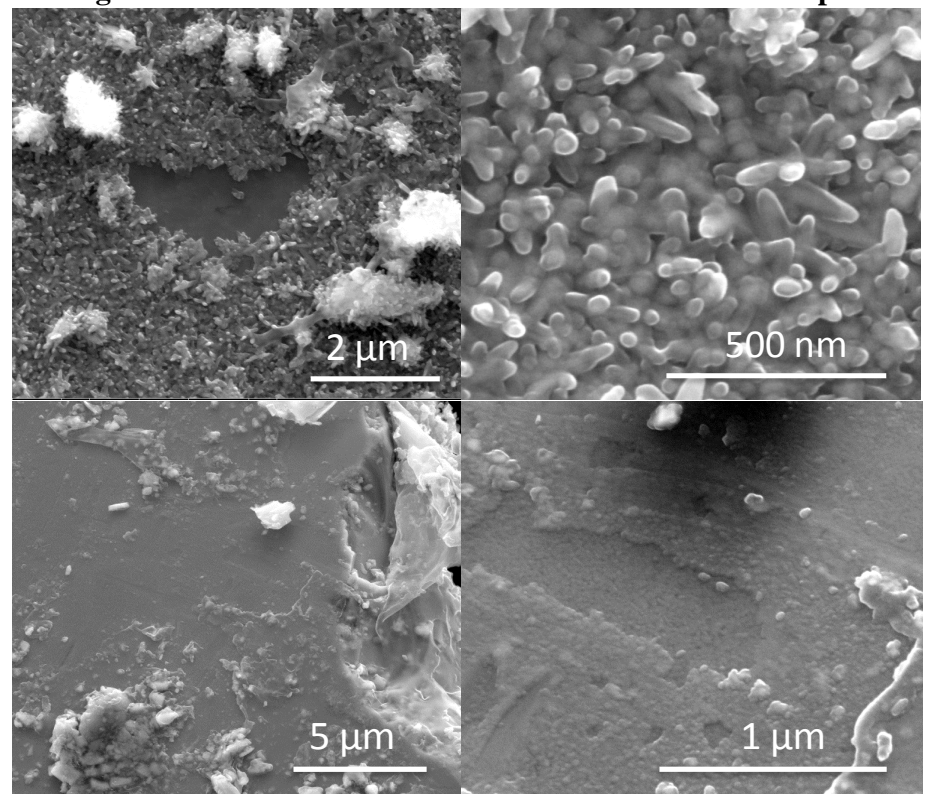

Figure 4. SEM images of pyrite surface coatings after dissolution in saturated calcite solution for 160 days with no added silicate (top images) and $20 \mathrm{mg} / \mathrm{L}$ (as Si ) added silicate (bottom images).
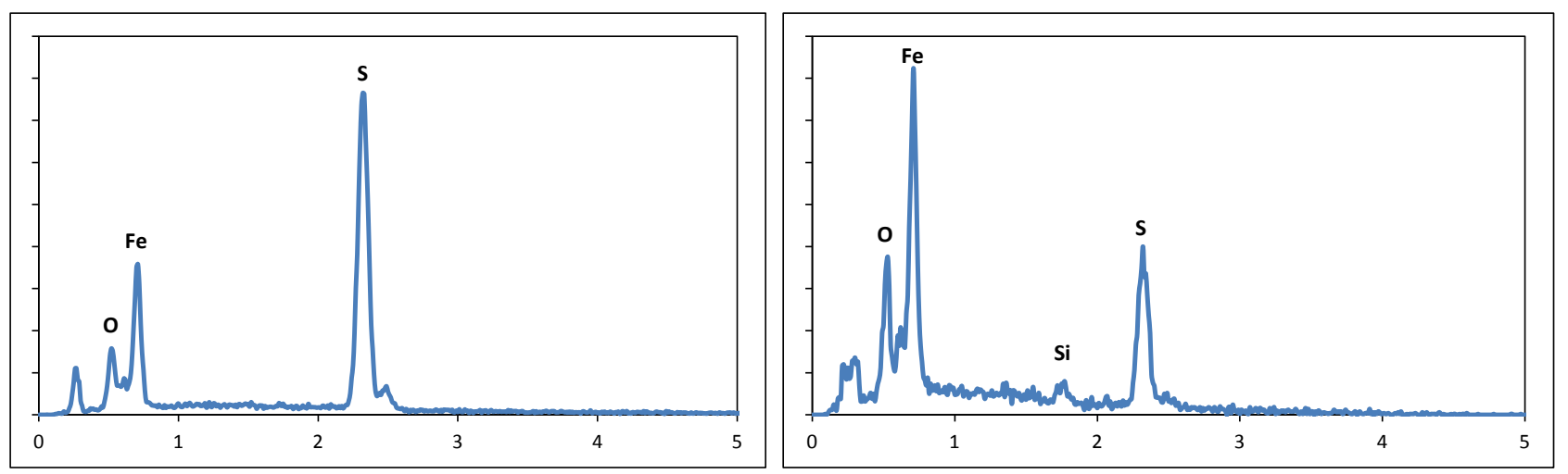

Figure 5. EDS spectra of pyrite surface coatings after dissolution in saturated calcite solution for 160 days with no added silicate (left) and $20 \mathrm{mg} / \mathrm{L}$ (as Si ) added silicate (right).

both coatings contain $\mathrm{Fe}, \mathrm{S}$ and $\mathrm{O}$. Si is only found in the less crystalline coating (amorphous-like coating) formed in the presence silicate. A number of studies examining the transformation from ferrihydrite (an amorphous phase) to goethite (a crystal phase) suggest that the addition of soluble silicate inhibits the crystallization process $[4,15,16,19]$. Our experimental results are consistent with these studies indicating that in solutions with added silicate, the conversion of the initially formed amorphous iron hydroxide is inhibited, while in the silicate free solution transformation to goethite is more pronounced. It appears that the presence of silicate inhibits transformation of amorphous iron oxy-hydroxide to a more crystalline goethite-like phase. The former phase appears to be less per- meable to oxygen and therefore pyrite oxidation is reduced more at circum-neutral $\mathrm{pH}$ when the solution concentration of silicate is higher.

\section{Conclusions}

Based on the results from the pyrite dissolution tests and the surface analyses, a possible mechanism for the formation and stabilization of iron oxy-hydroxide layers on pyrite during oxidation at $\mathrm{pH}>5.5$ was proposed. In the presence of dissolved silicate an amorphous layer with low oxygen permeability may form via:

- Ferrous ion is oxidized into ferric ion by dissolved oxygen;

- Ferric ion hydrolyses forming colloidal ferric hydroxide. Colloidal particles are aggregated onto the pyrite surface via adsorption eventually resulting in complete surface coverage;

- Silicate is absorbed into the colloidal iron hydroxide 
particles displacing hydroxyl groups and forming a Si-O-Fe bond during the formation of colloid particles;

- A layer with low oxygen permeability is established which reduces oxidation rates significantly. The transformation to goethite via dissolution and re-precipitation is retarded.

\section{Acknowledgements}

This research has been funded by an Australian Postgraduate Award Industry (APAI) through an Australian Research Council Linkage Project Grant with AMIRA International (Mr Gray Bailey). Sponsors of the Savage River Rehabilitation Project (SRRP), Hidden Valley Services, BHP Billiton Iron Ore, Rio Tinto Ltd. and Teck Ltd. to support the Project are gratefully acknowledged.

\section{REFERENCES}

[1] J. Satur, N. Hiroyoshi, M. Tsunekawa, M. Ito and H. Okamoto, "Carrier-Microencapsulation for Preventing Pyrite Oxidation,” International Journal of Mineral Processing, Vol.83, No. 3-4, 2007, pp. 116-124. doi:10.1016/j.minpro.2007.06.003

[2] E. Ahlberg and A. E. Broo, "Oxygen Reduction at Sulphide Minerals. 3. The Effect of Surface Pre-Treatment on the Oxygen Reduction at Pyrite," International Journal of Mineral Processing, 1996, Vol. 47, No. 1-2, pp. 49-60. doi:10.1016/0301-7516(95)00100-X

[3] N. Belzile, S. Maki, Y. W. Chen and D. Goldsack, "Inhibition of Pyrite Oxidation by Surface Treatment," Science of The Total Environment, Vol. 196, No. 2, 1997, pp. 177-186. doi:10.1016/S0048-9697(96)05410-1

[4] R. Cornell, R. Giovanoli and P. Schindler, "Effect of Silicate Species on the Transformation of Ferrihydrite into Goethite and Hematite in Alkaline Media," Clays and Clay Minerals, Vol. 35, No. 1, 1987, pp. 21-28. doi:10.1346/CCMN.1987.0350103

[5] D. B. Johnson and K. B. Hallberg, "Acid Mine Drainage Remediation Options: A Review," Science of The Total Environment, Vol. 338, No. 1-2, 2005, pp. 3-14. doi:10.1016/j.scitotenv.2004.09.002

[6] A. P. Chandra and A. R. Gerson, "The Mechanisms of Pyrite Oxidation and Leaching: A Fundamental Perspective," Surface Science Reports, Vol. 65, No. 9, 2010, pp. 293-315. doi:10.1016/j.surfrep.2010.08.003

[7] C. L. Caldeira, V. S. T. Ciminelli, A. Dias and K. Osseo-Asare, "Pyrite Oxidation in Alkaline Solutions: Nature of the Product Layer," International Journal of Mineral Processing, Vol. 72, No. 1-4, 2003, pp. 373-386. doi:10.1016/S0301-7516(03)00112-1

[8] V. P. Evangelou, "Pyrite Microencapsulation Technolo- gies: Principles and Potential Field Application,” Ecological Engineering, Vol.17, No. 2-3, 2001, pp. 165-178. doi:10.1016/S0925-8574(00)00156-7

[9] Lalvani, S. B., B. A. DeNeve and A. Weston, "Passivation of Pyrite Due to Surface Treatment," Fuel, Vol. 69, No. 12, 1990, pp. 1567-1569. doi:10.1016/0016-2361(90)90209-9

[10] K. Nyavor, N. O. Egiebor and P. M. Fedorak, "Suppression of Microbial Pyrite Oxidation by Fatty Acid Amine Treatment, Science of The Total Environment, Vol. 182, No. 1-3, 1996, pp. 75-83. doi:10.1016/0048-9697(95)05052-3

[11] C. L. Jiang, X. H. Wang and B. K. Parekh, "Effect of Sodium Oleate on Inhibiting Pyrite Oxidation,” International Journal of Mineral Processing, Vol. 58, No. 1-4, 2000, pp. 305-318. doi:10.1016/S0301-7516(99)00045-9

[12] D. M. C. Huminicki and J. D. Rimstidt, "Iron Oxyhydroxide Coating of Pyrite for Acid Mine Drainage Control. Applied Geochemistry,” Vol. 24, No. 9, 2009, pp. 1626-1634. doi:10.1016/j.apgeochem.2009.04.032

[13] R. S. C. Smart, S. D. Miller, W. S. Stewart, Y. Rusdinar, R. E. Schumann, N. Kawashima and J. Li, "In Situ Calcite Formation in Limestone-Saturated Water Leaching of Acid Rock Waste," Science of The Total Environment, Vol. 408, No. 16, 2010, pp. 3392-3402.

doi:10.1016/j.scitotenv.2010.04.028

[14] S. Miller, R. Schumann, R. Smart and Y. Rusdinar, “Ard Control by Limestene Induced Armouring and Passivation of Pyrite Mineral Surfaces, in ICARD," Skellefta Sweden, 2009, p. 11.

[15] L. Dyer, P. D. Fawell, O. M. G. Newman and W. R. Richmond, "Synthesis and Characterisation of Ferrihydrite/Silica Co-Precipitates," Journal of Colloid and Interface Science, Vol. 348, No. 1, 2010, pp. 65-70. doi:10.1016/j.jcis.2010.03.056

[16] U. Schwertmann and R. M. Cornell, "Iron Oxides in the Laboratory: Preparation and Characterization, ” 1991, Weinheim: VCH.

[17] S. Santomartino and J. A. Webb, "Estimating the Longevity of Limestone Drains in Treating Acid Mine Drainage Containing High Concentrations of Iron,” Applied Geochemistry,Vol. 22, No. 11, 2007, pp. 2344-2361. doi:10.1016/j.apgeochem.2007.04.020

[18] D. Mohapatra, P. Singh, W. Zhang and P. Pullammanappallil, "The Effect of Citrate, Oxalate, Acetate, Silicate and Phosphate on Stability of Synthetic Arsenic-Loaded Ferrihydrite and Al-Ferrihydrite, "Journal of Hazardous Materials, Vol. 124, No. 1-3, 2005, pp. 95-100. doi:10.1016/j.jhazmat.2005.04.025

[19] P. J. Swedlund, G. M. Miskelly and A. J. McQuillan, “An ATR-FTIR Study of Silicate Adsorption onto Ferrihydrite," Geochimica et Cosmochimica Acta, Vol. 70, No. 18,(Supplement), 2006, pp. A632. 